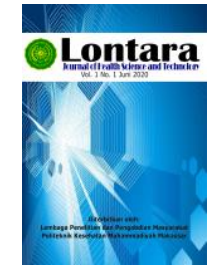

Lontara

Journal of Health Science and Technology

http://jurnal.poltekkesmu.online/lontarariset

Vol 2, No. 2, Desember 2021, pp 121-132

p-ISSN:0000-0000 dan e-ISSN: 2721-6179

DOI: $\underline{\text { https://doi.org/10.53861/lontarariset.v2i2 }}$

\title{
EFEKTIFITAS PEMBUATAN KOMPOS DENGAN AKTIVATOR EM4 DAN MOL
}

St. Mu'tamirah, Novi Poni Harwani

Sanitasi, Politeknik Kesehatan Muhammadiyah Makassar

Email: stmutamirah@gmail.com

\section{Artikel info}

\section{Artikel history:}

Received; 03-09-2021

Revised: 22-10-2021

Accepted; 24-11-2021

\section{Keyword:}

Compost, EM4 activator, MOL activator, organic waste

\section{Kata Kunci:}

Kompos, aktivator EM4 dan MOL, sampah organik

\begin{abstract}
A complicated problem for big city governments today is the increasing volume of solid waste, due to population growth and mobility so that the waste load will also increase, especially in metropolitan cities such as Makassar City. To reduce the rate of organic waste generation, which is $60 \%$, is to use organic waste as compost, both liquid and solid. The purpose of this study was to compare the effectiveness of composting with EM4 and MOL activators. The results of the study with the addition of EM4 activator, $M O L$ activator and without the addition of activator from the first day to the fourteenth day the compost structure was different. The addition of MOL produces a slightly coarser structure compared to the addition of EM4, while the compost without activator still smells like wet waste. The quality (C/N) of compost, the addition of $100 \mathrm{ml}$ of EM4 was in the optimum level, while the addition of $100 \mathrm{ml}$ of MOL was less than optimum.
\end{abstract}

Abstrak. Masalah yang pelik bagi pemerintah kota besar saat ini adalah volume limbah padat yang semakin meningkat, disebabkan karena pertumbuhan dan mobilitas penduduk sehingga beban sampah juga akan meningkat terutama kota metropolitan seperti Kota Makassar. Untuk menekan laju timbulan sampah organik yang berjumlah $60 \%$ adalah menggunakan sampah organik sebagai kompos baik cair maupun padat. Tujuan penelitian ini untuk mengetahui perbandingan efektifitas pembuatan kompos dengan activator EM4 dan MOL. Hasil penelitian dengan penambahan aktivator EM4, aktivator MOL dan tanpa penambahan aktivator mulai hari pertama sampai hari ke-empat belas struktur kompos berbeda. Penambahan MOL menghasilkan struktur yang sedikit kasar dibandingkan dengan penambahan EM4, sementara kompos tanpa aktivator masih berbau busuk layaknya limbah basah. Kualitas $(\mathrm{C} / \mathrm{N})$ kompos, penambahan $100 \mathrm{ml}$ EM4 berada dalam kadar optimum, sementara penambahan $100 \mathrm{ml}$ MOL kurang optimum.

Coresponden author: Email: stmutamirah@gmail.com

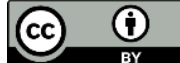

artikel dengan akses terbuka dibawah lisensi CC BY -4.0 


\section{PENDAHULUAN}

Masalah yang pelik bagi pemerintah Kota besar saat ini adalah volume limbah padat yang semakin meningkat, disebabkan karena pertumbuhan dan mobilitas penduduk sehingga beban sampah juga akan meningkat terutama kota metropolitan seperti Kota Makassar. Menurut Kementrian Lingkungan Hidup dan Kehutanan, “pertambahan jumlah penduduk berbanding lurus dengan jumlah sampah yang dihasilkan. Hitungan secara kasar, dengan jumlah penduduk Indonesia saat ini 250 juta orang, jika setiap orang menghasilkan sampah $0,7 \mathrm{~kg} / \mathrm{hari}$, maka timbulan sampah secara nasional mencapai 175 ribu ton/hari atau setara dengan 64 juta ton/tahun”. (KemenLHK, 2016)

Profil sampah di Indonesia masih didominasi sampah organik (60\%), sampah plastik (15\%), sampah kertas (10\%) dan lainnya (logam, kaca, kain, kulit) sekitar 15\%. Penimbunan sampah di TPA (69\%), kubur (10\%), daur ulang dengan prinsip 3R (7,5\%), bakar (5\%) dan lainnya tidak terkelola $(8,5 \%)$. Hal yang perlu dipikirkan untuk menekan laju timbulan sampah organik yang berjumlah $60 \%$ adalah menggunakan sampah organik sebagai kompos baik cair maupun padat. Kompos merupakan pupuk yang dibuat dari sampah organik yang sebagian besar berasal dari rumah tangga. Kompos adalah bahan organik yang mudah lapuk, seperti daun-daunan, sampah dapur, jerami, rumput serta kotoran lain, yang semua itu berguna untuk kesuburan tanah. Sampah organik kaya akan nutrisi, unsur hara dan mineral, unsur tersebut terdapat pada sampah organik. Secara alami, zat-zat tersebut mudah terurai dengan bantuan dari mikroorganisme yang hidup pada sampah organik.

Pengomposan bahan organik secara aerobik merupakan suatu proses humifikasi bahan organik tidak stabil (Rasio $\mathrm{C} / \mathrm{N}>25$ ) menjadi bahan organik stabil yang dicirikan oleh pelepasan panas dan gas dari substrat yang dikomposkan.

Komposter dengan bantuan aktivator kompos mampu mengubah sampah rumah tangga menjadi kompos hanya dalam waktu 7-14 hari. Khusus untuk pembuatan kompos dari sampah organik rumah tangga, digunakan bioaktivator Effective Mikroorganisme (EM). EM berfungsi untuk memperbaiki struktur dan tekstur tanah. Dengan demikian, penggunaan activator EM4 akan menghasilkan tanah lebih subur, sehat serta tahan terhadap serangan hama dan penyakit.4 Menurut Isroi (2015)" mikroorganisme local (MOL) adalah kumpulan mikroorganisme yang bisa "diternakkan". Fungsinya dalam konsep zero waste adalah untuk starter yang berfungsi sebagai bioaktivator dalam pembuatan kompos organik. Menurut Purwasasmita (2009) "MOL dapat digunakan baik sebagai bioaktivator pupuk hayati dan sebagai pestisida organik terutama sebagai fungisida".

Menurut Hersanti (2007), "MOL mudah dibuat, dan secara rinci MOL terdiri dari 3 komponen yaitu :

(a) Karbohidrat yang dapat berasal dari air taji, air cucian beras, nasi basi, singkong, kentang, gandum dan lain-lain.

(b) Glukosa, dapat berasal dari gula merah diencerkan, gula pasir, gula batu, air gula atau air kelapa. 
(c) Sumber bakteri berasal dari bahan-bahan makanan yang membusuk".

Peran MOL dalam proses pengomposan selain sebagai nutrisi juga berperan sebagai komponen bioreaktor, juga sangat ekonomis karena hampir tanpa biaya. Hasil analisis Purwasasmita (2009) "setiap MOL dengan bahan baku berbeda, akan mengandung jenis mikroba yang berbeda". Cara membuat MOL itu mudah, semua yang ada disekitar kita dapat dipakai, semua bahan dicampur dengan larutan yang mengandung glukosa seperti air nira, air gula dan air kelapa lalu ditutup dengan kertas, di biarkan sampai 7 hari. Penelitian tentang MOL yang telah dilakukan diantaranya hasil penelitian Muriani (2010), menyatakan kualitas MOL terbaik sebagai pupuk cair terdapat pada konsentrasi 300 gram daun gamal, lama fermentasi selama 3 pekan. MOL dari nasi basi dengan konsentrasi 300 gram nasi basi baik digunakan sebagai aktivator pembuatan kompos dengan perlakuan dosis $200 \mathrm{ml}$ MOL nasi basi.

\section{BAHAN DAN METODE}

Tujuan penelitian untuk mengetahui perbandingan efektivitas pembuatan kompos dengan activator EM4 dan MOL. Jenis penelitian yaitu eksperimen laboratorik yang bersifat deskriptif dan dilaksanakan di Workshop Prodi Sanitasi Politeknik Kesehatan Muhammadiyah Makassar.

Penelitian dimulai dengan mengaktifkan Larutan EM4: Buat larutan air gula dengan komposisi air 1,5 liter dengan gula 3-4 sendok makan, kocok sampai gulanya larut dalam air, tambahkan 2-3 tutup botol larutan EM4, kocok supaya rata, diamkan semalam supaya bakteri berkembang biak lagi.

Sedangkan untuk pembuatan larutan MOL: Kepal-kepal nasi basi sebesar bola pimpong, letakkan bola-bola nasi tersebut didalam kardus bekas, lalu tutup dengan dedaunan (misalnya daun pisang). Dalam tempo 3 hari, akan tumbuh jamur-jaamur berwarna kuning, jingga dan merah. Letakkan bola-bola nasi tersebut didalam kardus bekas, lalu tutup dengan dedaunan (misalnya daun pisang). Dalam tempo 3 hari, akan tumbuh jamur-jamur berwarna kuning, jingga dan merah, Buat larutan gula dengan cara mencampur dan mengocok gula dengan air, Ambil bola-bola nasi yang telah di tumbuhi jamur, masukkan ke dalam wadah plastik, lalu campur larutan gula secukupnya. Biarkan selama seminggu. Setelah satu minggu, cairan akan mengeluarkan bau seperti tape. Hal itu menandakan bahwa cairan ini sudah bisa dipakai sebagai starter. (Hayat, dkk., 2017)

Sementara itu untuk pembuatan alat Komposter: Sembilan buah tong/ember cat dilubangi masing-masing sebanyak satu lubang di bagian samping sekitar $10 \mathrm{~cm}$ dari dasar tong/ember cat, Setelah itu dipasangkan kran air di masing-masing ember yang sudah dilubangi dengan menggunakan lem, Siapkan sembilan buah lempeng plastik kemudian dibuat lubang dari masing-masing lempeng plastik tersebut, yang berfungsi sebagai penyaring, Siapkan sembilan pipa kemudian dipotong bagian samping sebanyak 2 potongan saling berhadapan dari masing-masing pipa, Kemudian sembilan buah lempeng plastik dipasangkan pipa yang sudah dipotong dengan menggunakan kran, Kemudian 
dimasukkan lempeng plastik yang dipasangi pipa ke dalam tong dekomposer yang sudah disiapkan. Tong dekomposter siap di pakai.

Prosedur Pembuatan Kompos: Bahan : Sampah organik, Larutan EM4, Larutan MOL, air, Cara kerja: Siapkan sampah organik (terurai) seperti sayur-sayuran, kulit buah dan lain-lain, Potong/cacah sampah organik terlebih dahulu menjadi ukuran yang lebih kecil 2-4 cm, Pisahkan sampah organik yang telah di cacah menjadi 9 bagian dengan jenis sampah yang sama. Setelah itu sampah dimasukkan ke dalam masing-masing kantong, Timbang sampah organik di atas timbangan yang sudah disiapkan dengan berat yang sama yaitu sebanyak 5-10 kg/sampah organik, Setelah itu sampah organik di lepaskan dari kantong dan dimasukkan ke dalam ember/tong dekomposter yang sudah disiapkan, Ember/tong dekomposter pertama yang sudah terisi sampah organik di semprotkan dengan bioaktivator yaitu larutan EM4 hingga merata dengan talkaran 1 tutup botol/10 cc di campur dengan \pm 1 liter air ( 1 liter campuran dapat dipakai untuk 10 kali penyemprotan ), Ember atau tong dekomposter kedua disemprotkan dengan biaktivator yaitu larutan MOL hingga merata dengan takaran yang sama seperi ember pertama yaitu 1 tutup botol/ $10 \mathrm{cc}$ di campur dengan kurang lebih 1 liter air ( 1 liter campuran dapat dipakai untuk 10 kali penyemprotan), Ember atau tong dekomposter ketiga tidak menggunakan activator, Tutup Sembilan ember/tong dekomposter rapat-rapat, Diamkan selama kurang lebih 7-14 hari agar terjadi composting. Lakukan penyemprotan setiap kali melihat atau membuka sampah kecuali pada ember/tong ketiga (control) dan tutup kembali ember / tong dekomposter rapat-rapat, Selama $\pm 7-14$ hari peneliti melakukan 4 kali mengamatan atau 2 kali dalam seminggu, Kemudian tuang kompos yang telah berbentuk bubur, Kompos merupakan pupuk yang dibuat dari sampah organik yang sebagaian besar berasal dari rumah tangga, Aktivator adalah adalah bahan tambahan yang mampu meningkatkan penguraian mikrobiologis dalam tumpukan bahan organik, Larutan Mikroorganisme Lokal (MOL) adalah cairan yang terbuat dari bahan-bahan alami seperti sisa pencucian beras, yang disukai sebagai media hidup dan berkembangnya mikroorganisme, EM4 (Effective Mikroorganisme 4) merupakan bakteri fermentasi bahan organik tanah untuk menyuburkan tanaman dan menyehatkan tanah.

\section{HASIL PENELITIAN}

1. Hasil pengamatan Aktivator EM4 secara fisik melalui warna, tekstur dan bau selama proses pengomposan

Hasil penelitian kompos setelah dilakukan penyemprotan dari ke tiga buah wadah yang masing-masing 10 kali $(10 \mathrm{cc})$ penyemprotan untuk setiap pengecekan sehingga mengalami perubahan warna coklat kehitaman. Hari 6-9 berwarna hitam dan terjadi perubahan warna coklat-hitam, Hari 912, tekstur awal sampah organik dan sayur-sayuran yang ditambah aktivator EM4 pada hari pertama tekstur kompos kasar, hari ke 12 tekstur sampah organik berubah menyerupai tekstur tanah atau cukup efektif. Selama pengamatan secara fisik, bau pada sampah organik pada awal pengomposan seperti aslinya, hari ke 3-12 mulai terjadi proses penguraian lalu baunya sudah mulai berubah karena proses 
dekomposisi sehingga menimbulkan gas, hari ke 12-14 bau gas dari proses penguraian sampah organik sudah semakin berkurang dan berubah baunya menjadi bau tanah dan penambahan serbuk gergaji untuk mempercepat pengeringan.

Tabel 1. Hasil pengamatan Aktivator EM4 secara fisik melalui warna, tekstur dan bau selama proses pengomposan

\begin{tabular}{|c|c|c|c|c|c|}
\hline No & Jenis Bahan & Hari Ke- & Perubahan warna & Tekstur & Bau \\
\hline \multirow[t]{5}{*}{1} & \multirow[t]{5}{*}{$\begin{array}{l}\text { Sayur-sayuran } \\
\text { + Aktivator EM4 }\end{array}$} & $1-3$ & $\begin{array}{l}\text { Warna asli sampah } \\
\text { organik }\end{array}$ & Kasar & $\begin{array}{l}\text { Bau asli dari sampah } \\
\text { organik }\end{array}$ \\
\hline & & $3-6$ & Coklat & Lembab & Bau Busuk \\
\hline & & $6-9$ & Hitam & Lembab & $\begin{array}{l}\text { Bau khas sampah } \\
\text { organik }\end{array}$ \\
\hline & & $9-12$ & Coklat kehitaman & Lembab & $\begin{array}{l}\text { Bau khas sampah } \\
\text { organik }\end{array}$ \\
\hline & & $12-14$ & $\begin{array}{l}\text { Coklat } \\
\text { Kehitaman }\end{array}$ & $\begin{array}{l}\text { Tekstur } \\
\text { Tanah }\end{array}$ & Bau Tanah \\
\hline \multirow[t]{5}{*}{2} & \multirow[t]{5}{*}{$\begin{array}{l}\text { Sayur-sayuran + } \\
\text { Aktivator EM4 }\end{array}$} & $1-3$ & $\begin{array}{l}\text { Warna asli sampah } \\
\text { organik }\end{array}$ & Kasar & $\begin{array}{l}\text { Bau asli dari sampah } \\
\text { organik }\end{array}$ \\
\hline & & $3-6$ & Coklat & Lembab & Bau Busuk \\
\hline & & $6-9$ & Hitam & Lembab & $\begin{array}{l}\text { Bau khas sampah } \\
\text { organik }\end{array}$ \\
\hline & & $9-12$ & Coklat kehitaman & Lembab & $\begin{array}{l}\text { Bau khas sampah } \\
\text { organik }\end{array}$ \\
\hline & & $12-14$ & $\begin{array}{l}\text { Coklat } \\
\text { Kehitaman }\end{array}$ & $\begin{array}{l}\text { Tekstur } \\
\text { Tanah }\end{array}$ & Bau Tanah \\
\hline \multirow[t]{5}{*}{3} & \multirow[t]{5}{*}{$\begin{array}{l}\text { Sayur-sayuran + } \\
\text { Aktivator EM4 }\end{array}$} & $1-3$ & $\begin{array}{l}\text { Warna asli sampah } \\
\text { organik }\end{array}$ & Kasar & $\begin{array}{l}\text { Bau asli dari sampah } \\
\text { organik }\end{array}$ \\
\hline & & $3-6$ & Coklat & Lembab & Bau Busuk \\
\hline & & $6-9$ & Hitam & Lembab & $\begin{array}{l}\text { Bau khas sampah } \\
\text { organik }\end{array}$ \\
\hline & & $9-12$ & Coklat kehitaman & Lembab & $\begin{array}{l}\text { Bau khas sampah } \\
\text { organik }\end{array}$ \\
\hline & & $12-14$ & $\begin{array}{l}\text { Coklat } \\
\text { Kehitaman }\end{array}$ & $\begin{array}{l}\text { Tekstur } \\
\text { Tanah }\end{array}$ & Bau Tanah \\
\hline
\end{tabular}

Sumber: Data primer (2021)

Berdasarkan hasil penelitian yang dilakukan, media atau bahan yang digunakan dalam pembuatan kompos yakni sisa sayur-sayuran dengan penambahan aktivator EM4 dengan cara disemprotkan secara merata dengan jumlah yang sama setiap pengecekan yaitu 10 kali penyemprotan (10 cc). pada hari 1-3 masih belum menunjukkan perubahan warna. Hal ini terjadi karena sampah organik masih dalam proses dekomposisi baik sehingga bentuk masih seperti dengan bentuk aslinya. Hari ke 3-6 terjadi perubahan warna dari warna asli bahan organik menjadi warna kecoklatan, disebabkan karena terjadinya proses penguraian sehingga terjadi perubahan pada sampah organik tersebut. Hari ke 6-9 sampah organik terjadi perubahan dari warna coklat menjadi warna hitam. Hari ke 9-12 sampah organik sudah berubah warna coklak-hitam, perubahan warna ini disebabkan sampah 
organik yang sudah terurai ditambah dengan adanya perlakuan kompos sehingga warna yang sebelumnya coklat, mulai menjadi hitam disebabkan karena sifat kelembaban yang rendah.

Percobaan kompos dengan bahan sampah organik dengan aktivator EM4, untuk hari 1-2 tekstur kompos masih sama seperti aslinya. Hari ke 3-12 bahan kompos tingkat kelembaban tinggi, pengadukan terhadap kompos harus sering dilakukan agar teksturnya terurai. Hari ke 12-14 tekstur kompos sudah mulai lebih halus dan tidak kasar, tekstur pada akhir pengomposan juga sudah sama dengan tekstur tanah.

Hasil penelitian terhadap kompos dengan bahan dari sisa sayuran dengan aktivator EM4, hari 1-3 menunjukkan bau dari sampah organic. Hari ke 3-6 sudah menimbulkan bau yang membusuk, lalu di hari ke 6-12 kompos mengeluarkan bau dari sampah organik yang tingkat kelembabannya tinggi. Sampah organik yang berbau ini menunjukkan bahwa telah terjadi peningkatan kadar air pada proses pengomposan sehingga zat unsur hara akan tercuci, akibatnya aktivitas mikroba akan menurun dan akan terjadi fermentasi yang menimbulkan bau tidak sedap. Hari ke 12-14 kompos sudah mengalami penurunan bau yang tidak sedap menjadi berbau tanah, hal ini terjadi karena kadar air pada kompos sudah berkurang dan juga dilakukan penambahan serbuk gergaji untuk mempercepat pengeringan.

EM4 sebagai inukulon untuk meningkatkan keragaman dan populasi mikroorganisme didalam tanah dan tanaman yang selanjutnya dapat meningkatkan kesehatan, pertumbuhan, kualitas dan kuantitas produksi tanaman.

2. Hasil pengamatan aktivator MOL secara fisik melalui warna, tekstur dan bau selama proses Pengomposan

Pengomposan pada eksperimen kompos setelah dilakukan penyemprotan dari ke tiga buah wadah yang masing-masing $10 \mathrm{kali}(10 \mathrm{cc})$ penyemprotan untuk setiap pengecekan sampai terjadi perubahan warna menjadi coklat kehitaman. Hari ke 9-12 warna hitam berubah warna menjadi coklat kehitaman pada hari ke 12-14.

Tabel 2. Hasil pengamatan aktivator MOL secara fisik melalui warna, tekstur dan bau selama proses pengomposan

\begin{tabular}{clllll}
\hline No & Jenis Bahan & Hari Ke- & Perubahan warna & \multicolumn{1}{c}{ Tekstur } & \multicolumn{1}{c}{ Bau } \\
\hline $\mathbf{1}$ & $\begin{array}{l}\text { Sayur- } \\
\text { sayuran } \\
+ \text { Aktivator } \\
\text { MOL }\end{array}$ & $1-3$ & $\begin{array}{l}\text { Warna asli sampah } \\
\text { organik }\end{array}$ & Kasar & $\begin{array}{l}\text { Bau asli dari sampah } \\
\text { organik }\end{array}$ \\
\cline { 2 - 5 } & 6-6 & Coklat & Kasar & $\begin{array}{l}\text { Bau asli dari sampah } \\
\text { organik }\end{array}$ \\
\cline { 2 - 5 } & $9-12$ & Hitam & Lembab & $\begin{array}{l}\text { Bau khas sampah } \\
\text { organik }\end{array}$ \\
\cline { 2 - 5 } & $12-14$ & Coklat Kehitaman & $\begin{array}{l}\text { Tekstur sedikit } \\
\text { lembab }\end{array}$ & $\begin{array}{l}\text { Bau khas sampah } \\
\text { organik }\end{array}$ \\
\hline $\mathbf{2}$ & $\begin{array}{l}\text { Sayur- } \\
\text { sayuran } \\
+ \text { Aktivator }\end{array}$ & $1-3$ & Warna asli sampah & Kasar & $\begin{array}{l}\text { Bau asli dari sampah } \\
\text { organik }\end{array}$ \\
\cline { 2 - 5 } & organik & Coklat & Kasar & Bau asli dari sampah \\
\hline
\end{tabular}


Efektifitas Pembuatan Kompos Dengan Aktivator EM4 dan MOL Dalam Pembuatan Kompos

\begin{tabular}{|c|c|c|c|c|c|}
\hline & \multirow[t]{4}{*}{ MOL } & & & \multicolumn{2}{|r|}{ organik } \\
\hline & & $6-9$ & Coklat & Lembab & $\begin{array}{l}\text { Bau khas sampah } \\
\text { organik }\end{array}$ \\
\hline & & $9-12$ & Hitam & Lembab & $\begin{array}{l}\text { Bau khas sampah } \\
\text { organik }\end{array}$ \\
\hline & & $12-14$ & Coklat Kehitaman & $\begin{array}{l}\text { Tekstur sedikit } \\
\text { lembab }\end{array}$ & Bau Tanah \\
\hline \multirow[t]{5}{*}{3} & \multirow{5}{*}{$\begin{array}{l}\text { Sayur- } \\
\text { sayuran } \\
+ \text { Aktivator } \\
\text { MOL }\end{array}$} & $1-3$ & $\begin{array}{l}\text { Warna asli sampah } \\
\text { organik }\end{array}$ & Kasar & $\begin{array}{l}\text { Bau asli dari sampah } \\
\text { organik }\end{array}$ \\
\hline & & $3-6$ & Coklat & Kasar & $\begin{array}{l}\text { Bau asli dari sampah } \\
\text { organik }\end{array}$ \\
\hline & & $6-9$ & Coklat & Lembab & $\begin{array}{l}\text { Bau khas sampah } \\
\text { organik }\end{array}$ \\
\hline & & $9-12$ & Hitam & Lembab & $\begin{array}{l}\text { Bau khas sampah } \\
\text { organik }\end{array}$ \\
\hline & & $12-14$ & Coklat Kehitaman & $\begin{array}{l}\text { Tekstur sedikit } \\
\text { Lembab }\end{array}$ & Bau Tanah \\
\hline
\end{tabular}

Sumber: Data primer (2021)

Pada tabel 2, tekstur sampah organik di tambahkan aktivator MOL, pada awal pengomposan tekstur sampah organik kasar sedangkan pada hari ke 12 tekstur sampah organik seperti tekstur tanah namun kelembabannya masih tinggi sehingga kurang efektif.

Berdasarkan pengamatan secara fisik, bau sampah organic pada hari pertama masih seperti bau asli sampah organik, hari ke 6-12 sudah mulai mengeluarkan bau kurang sedang karena terjadi proses penguraian oleh mikroorganisme,dan hari ke 12-14 bau kompos sudah berubah menjadi bau alami tanah dan penambahan serbuk gergaji untuk mempercepat pengeringan.

3. Hasil pengamatan tanpa aktivator secara fisik melalui warna, tekstur dan bau selama proses pengomposan.

Kompos setelah dilakukan penyemprotan dari ke tiga buah wadah yang masing-masing $10 \mathrm{kali}$ (10 cc) penyemprotan untuk setiap pengecekan sehingga mengalami perubahan warna. Hari ke 9-12 warna Coklat dan mengalami perubahan menjadi Hitam pada hari ke 12-14.

Tabel 3. Hasil pengamatan tanpa aktivator secara fisik melalui warna, tekstur dan bau selama proses pengomposan.

\begin{tabular}{llllll}
\hline No. & Jenis Bahan & Hari Ke- & Perubahan warna & Tekstur & Bau \\
\hline $\mathbf{1}$ & $\begin{array}{l}\text { Sayur-sayuran } \\
\text { Tanpa }\end{array}$ & $1-3$ & $\begin{array}{l}\text { Warna asli sampah } \\
\text { organik }\end{array}$ & Kasar & $\begin{array}{l}\text { Bau asli dari sampah } \\
\text { organik }\end{array}$ \\
\cline { 2 - 5 } $\begin{array}{l}\text { Penambahan } \\
\text { Aktivator }\end{array}$ & $3-6$ & Sedikit Coklat & Kasar & $\begin{array}{l}\text { Bau asli dari sampah } \\
\text { organik }\end{array}$ \\
\cline { 2 - 5 } & 6-9 & Coklat & Lembab & Bau Busuk \\
\cline { 2 - 5 } & $9-12$ & Coklat & Lembab & Bau Busuk \\
\cline { 2 - 5 } & $12-14$ & Hitam & Lembab & Bau Busuk
\end{tabular}




\begin{tabular}{|c|c|c|c|c|c|}
\hline \multirow[t]{5}{*}{2} & \multirow{5}{*}{$\begin{array}{l}\text { Sayur-sayuran } \\
\text { Tanpa } \\
\text { Penambahan } \\
\text { Aktivator }\end{array}$} & $1-3$ & $\begin{array}{l}\text { Warna asli sampah } \\
\text { organik }\end{array}$ & Kasar & $\begin{array}{l}\text { Bau asli dari sampah } \\
\text { organik }\end{array}$ \\
\hline & & $3-6$ & Sedikit Coklat & Kasar & $\begin{array}{l}\text { Bau asli dari sampah } \\
\text { organik }\end{array}$ \\
\hline & & $6-9$ & Coklat & Lembab & Bau Busuk \\
\hline & & $9-12$ & Coklat & Lembab & Bau Busuk \\
\hline & & $12-14$ & Hitam & Lembab & Bau Busuk \\
\hline \multirow[t]{5}{*}{3} & \multirow{5}{*}{$\begin{array}{l}\text { Sayur-sayuran } \\
\text { Tanpa } \\
\text { Penambahan } \\
\text { Aktivator }\end{array}$} & $1-3$ & $\begin{array}{l}\text { Warna asli sampah } \\
\text { organik }\end{array}$ & Kasar & $\begin{array}{l}\text { Bau asli dari sampah } \\
\text { organik }\end{array}$ \\
\hline & & $3-6$ & Sedikit Coklat & Kasar & $\begin{array}{l}\text { Bau asli dari sampah } \\
\text { organik }\end{array}$ \\
\hline & & $6-9$ & Coklat & Lembab & Bau Busuk \\
\hline & & $9-12$ & Coklat & Lembab & Bau Busuk \\
\hline & & $12-14$ & Hitam & Lembab & Bau Busuk \\
\hline
\end{tabular}

Sumber: Data primer (2021)

Hasil pada tabel 3, tekstur awal sampah organik tanpa penambahan aktivator, teksturnya kasar sedangkan pada hari ke 12 teksturnya sudah terjadi perubahan menjadi lebih halus.

Pengamatan secara fisik, bau pada hari pertama pengomposan seperti bau asli sampah organik, pada hari ke 6-12 sudah menimbulkan bau yang kurang sedap karena terjadi proses penguraian oleh mikroorganisme, pada hari ke 12-14 bau dari sampah organik akan berubah menjadi bau yang membusuk.

\section{PEMBAHASAN}

Percobaan yang dilakukan, sampah organik ditambah aktivator EM4 dengan cara disemprotkan secara merata dengan jumlah yang sama setiap pengecekan yaitu 10 kali penyemprotan (10 cc). hari 1-3 masih menunjukan warna aslinya (hijau). disebabkan karena sampah organik belum terdekomposisi dengan baik sehingga masih seperti bentuk aslinya. Hari ke 3-6 mulai terjadi perubahan warna dari warna asli sampah organik menjadi warna kecoklatan, dikarenakan sampah organik tingkat kelembabannya sudah mulai meningkat. hari ke 6-9 sampah organik berubah warna menjadi hitam, dikarenakan sampah organik sudah mengalami dekomposisi, Hari ke 9-12 sampah organik sudah mengalami perubahan dari warna kecoklatan menjadi warna kehitaman, perubahan ini karena sampah organik sudah mengalami penguraian, dari warna hitam berubah menjadi cokelat kehitaman karena tingkat kelembaban yang mulai menurun.

Percobaan pada sampah organik ditambah aktivator EM4, hari 1-2 tekstur sampah organik sama seperti aslinya (kasar). hari ke 3-12 sampah organik tingkat kelembaban mulai meningkat, pengadukan terhadap sampah organik harus sering dilakukan agar teksturnya tidak menggumpal. Hari ke 12-14 tekstur sampah organik sudah berbentuk serbuk dan tidak kasar, tekstur pada akhir pengomposan sama dengan tekstur tanah. 
Percobaan terhadap sampah organik ditambah aktivator EM4, hari 1-3 masih menunjukkan bau asli sampah organik tersebut. Hari ke 3-6 sudah menimbulkan bau yang menyengat, Hari ke 6-12 sampah organik mengeluarkan bau khas karena tingkat kelembaban semakin meningkat. Kondisi sampah organik yang berbau menunjukkan bahwa terjadi peningkatan kadar air pada proses pematangan kompos sehingga zat unsur hara akan terbilas, disebabkan bakteri aerob mati sehingga terjadi fermentasi yang menimbulkan bau tidak sedap. Hari ke 12-14 sampah organik sudah tidak berbau menyengat dan berubah menjadi bau tanah, disebabkan karena kadar air pada sampah organik sudah mulai berkurang, juga dilakukan penambahan serbuk gergaji untuk mempercepat pengeringan.

Berdasarkan penelitian, pembuatan kompos dengan penambahan aktivator MOL yaitu disemprotkan secara merata dengan jumlah yang sama setiap pengecekan yaitu 10 kali penyemprotan (10 cc). Hari 1-3 masih menunjukkan warna asli (hijau), sebagaimana warna sampah organik tersebut. Hal ini terjadi karena masih terjadi proses penguraian oleh mikroorgaanisme sehingga teksturnya masih seperti tekstur aslinya. Hari ke 3-9 mulai terjadi perubahan warna dari warna asli sampah organik menjadi warna coklat, hal ini disebabkan kelembaban kompos sudah mulai meningkat. Hari ke 9-12 sampah organik berubah warna menjadi hitam, perubahan warna ini disebabkan karena sampah organik sudah mengalami proses dekomposisi. hari ke 12-14 kompos sudah berubah warna coklat kehitaman, perubahan warna ini disebabkan karena sampah organik sudah terurai ditambah dengan adanya perlakuan sampah organik sehingga warna yang sebelumnya berwarna hitam akibat kelembaban yg tinggi, mulai berubah warna menjadi coklat kehitaman karena kelembaban yang sudah mulai berkurang.

Percobaan pada sampah organik dengan aktivator MOL, hari 1-6 teksturnya masih sama dengan aslinya. Hari ke 6-12 sampah organik sudah mulai kelembabannya meningkat, pengadukan terhadap sampah organik harus sering dilakukan agar teksturnya tidak menggumpal dan cepat terjadi pemasakan. Hari ke 12-14 tekstur sampah organik sudah menjadi remah dan tidak kasar, namun tekstur pada akhir pengomposan masih cukup tinggi kelembabannya.

Percobaan pada sampah organik dengan aktivator MOL, dari hari 1-6 masih menunjukkan bau asli dari sampah organik tersebut. Hari ke 6-12 kompos berbau khas sampah organik karena terjadi proses dekomposisi oleh mikroorganisme dengan tingkat kelembaban yang tinggi. Kondisi proses pengomposan yang berbau menyengat ini menunjukkan bahwa telah terjadi peningkatan kadar air pada proses pengomposan sehingga zat unsur hara akan terbilas, ini disebabkan karena bakteri aerobik akan mati dan akan terjadi fermentasi yang menimbulkan bau tidak sedap. Hari ke 12-14 sampah organik mengalami perubahan bau dari bau yang menyengat menjadi bau tanah, hal ini terjadi karena kadar air pada sampah organik sudah mulai menurun dan juga penambahan serbuk gergaji untuk mempercepat pengeringan.

Berdasarkan hasil penelitian yang dilakukan, pembuatan kompos tanpa penambahan activator pada hari 1-3 masih menunjukan warna aslinya (hijau), sebagaimana warna sampah organik tersebut. 
Hal ini terjadi karena sampah organik belum terurai dengan baik sehingga bentuknya masih seperti dengan bentuk aslinya. Hari ke 3-6 mulai terjadi perubahan warna dari warna asli sampah organik menjadi sedikit berwarna coklat, hal tersebut dikarenakan sampah organik belum betul terurai. Hari ke 6-12 sampah organik berubah warna menjadi coklat, perubahan warna ini dikarenakan kompos yang sudah mengalami penguraian. Lalu pada hari ke 12-14 kompos menunjukkan warna hitam.

Pada pembuatan kompos tanpa aktivator, Hari 1-6 tekstur sampah organik masih sama seperti aslinya. Hari ke 6-14 sampah organik mulai terjadi proses penguraian oleh mikroorganisme dengan tingkat kelembaban yang cukup tinggi, pengadukan terhadap sampah organik harus sering dilakukan agar teksturnya tidak menggumpal. Namun tekstur sampah organik tetap dengan kelembaban yang cukup tinggi, hal ini dikarenakan bakteri pengurai yang ada tidak bekerja dengan baik.

Hasil penelitian terhadap pembuatan kompos tanpa aktivator, Hari 1-6 tetap dengan bau asli dari sampah organik tersebut. Hari ke 6-14 sampah organik mengeluarkan bau busuk dari sampah organik yang mulai tingkat kelembaban cukup tinggi. Kondisi sampah organik yang berbau busuk menunjukkan proses penguraian tidak berjalan dengan baik.

Penelitian dan pengamatan terhadap kompos yang telah dilakukan dengan penambahan EM4, MOL dan tanpa penambahan aktivator, untuk hari pertama sampai hari ke-3 masih menunjukkan kesamaan yaitu dengan warna hijau atau warna asli dari bahan organik tersebut. Untuk kompos dengan penambahan EM4 sebagai aktivator pada hari ke 3-6 mengalami perubahan warna lebih cokelat dari pada kompos dengan penambahan MOL. Selanjutnya pada hari ke 6-9 terjadi perbedaan dimana kompos dengan aktivator EM4 berubah menjadi warna hitam, sedangkan kompos dengan Penambahan MOL masih tetap warna coklat begitu juga dengan kompos tanpa penambahan aktivator. Pada hari ke 9-12 kompos dengan aktivator EM4 sudah mulai berubah menjadi cokelat kehitaman artinya kompos dengan penambahan aktivator EM4 lebih efektif, sedangkan kompos dengan penambahan MOL masih berwarna hitam yang menandakan bahwa kurang efektif.

Penelitian pada kompos dengan penambahan aktivator EM4, MOL dan tanpa penambahan aktivator. Selama pengomposan mulai pada hari pertama sampai pada hari ke-14 tekstur kompos dengan penambahan EM4 sebagai aktivator terjadi perubahan menjadi tekstur tanah berbeda dengan kompos dengan penambahan MOL yang teksturnya masih sedikit lembab, terlebih lagi pada kompos tanpa penambahan aktivator yang teksturnya masih dalam keadaan lembab. Penambahan MOL menghasilkan tekstur yang sedikit kasar dibanding dengan tekstur kompos dari penambahan EM4.

Hasil penelitian terhadap kompos dengan penambahan aktivator EM4, MOL dan juga tanpa penambahan aktivator selama pengomposan mulai pada hari pertama hingga hari ke-14 bau kompos dengan penambahan aktivator EM4 dan MOL mengalami kesamaan menjadi bau tanah dan juga dilakukan penambahan serbuk gergaji untuk mempercepat pengeringan, sedangkan kompos tanpa aktivator masih berbau busuk layaknya limbah sayuran.

Kualitas $(\mathrm{C} / \mathrm{N})$ kompos dengan bantuan $100 \mathrm{ml}$ Effective Microorganism-4 (EM4) berada dalam kadar optimum. Kualitas kompos dengan bantuan 100 ml Microorganism Lokal (MOL) kurang 
dari optimum. Perbedaan ini disebabkan karena MOL hanya terdiri dari dua jenis bakteri saja (saccharomyces dan lactobacillus) sedangkan EM4 mengandung beberapa macam mikrorganisme yang terdiri dari bateri asam laktat, bakteri fotosintetik, actinomycetes, Streptomyces, dan ragi yang berperan dalam meningkatkan ketersediaan unsur hara, senyawa organik pada tanaman dan meningkatkan kadar nitrogen. (Djuarnani, 2004)

\section{KESIMPULAN}

Kompos dari bahan organik seperti sisa sayur-sayuran dengan penambahan aktivator EM4 sebanyak $10 \mathrm{cc}$ atau dengan 10 kali penyemprotan, lebih efektif karena hanya membutuhkan waktu selama 14 hari untuk menjadi kompos. Kompos dari bahan organik seperti sisa sayur-sayuran dengan penambahan aktivator MOL sebanyak $10 \mathrm{cc}$ atau dengan 10 kali penyemprotan, kurang efektif karena membutuhkan waktu lebih dari 14 hari untuk menjadi kompos yang sempurna, terlebih lagi dengan pengomposan tanpa bantuan aktivator yang membutuhkan waktu cukup lama untuk menjadi kompos. Dari hasil penelitian dan pembahasan dapat dilihat hasil bahwa kualitas $(\mathrm{C} / \mathrm{N})$ kompos dengan bantuan Effective Mikroorganisme-4 (EM4) berada dalam kadar optimum atau efektif. Sedangkan kualitas kompos dengan bantuan Mikroorganisme Lokal (MOL) kurang optimum atau tidak efektif.

\section{SARAN}

Diharapkan untuk penelitian selanjutnya dapat memperhatikan besar kecilnya bahan organik sebelum melakukan pengomposan dengan tujuan untuk mempercepat penghancuran atau penguraian. Mengingat bahan yang dijadikan sebagai kompos dan aktivator maka perlu dilakukan penelitian dengan media yang berbeda yang mungkin lebih efektif, Bagi peneliti selanjutnya dapat menambahkan jumlah atau dosis aktivator dan juga menggunakan serbuk gergaji untuk proses pengeringan kompos sehingga dapat mempercepat kematangan kompos.

\section{UCAPAN TERIMA KASIH}

Terima kasih kami ucapkan kepada Pimpinan Poltekkesmu Makassar yang telah memberikan izin penelitian, Kaprodi Sanitasi serta seluruh civitas akademika Poltekkesmu Makassar yang telah membantu penulis sehingga penelitian kami dapat terselesaikan.

\section{DAFTAR PUSTAKA}

Aisyah, N. (Ed.). (2016). Memproduksi Kompos dan Mikro Organisme Lokal (MOL). Bibit Publisher.

Djuarnani, I. N. (2005). Cara cepat membuat kompos. AgroMedia.

Harizena, I. N. D. (2012). Pengaruh Jenis dan Dosis MOL terhadap Kualitas Kompos Sampah Rumah Tangga. Skripsi. Konsentrasi Ilmu Tanah dan Lingkungan Jurusan Agroekoteknologi, Fakultas Pertanian, Universitas Udayana. Denpasar. 
Hayat, A.M. Fadhil, Ikbal, Muh., Hasan, Irnawati. 2017. Efektivitas EM4 (Effective Microorganisms4) dan MOL (Mikroorganisme Lokal) Sebagai Aktivator Pada Pembuatan Kompos Skala Rumah Tangga di Kota Makassar. Jurnal Masker Medika. Volume 5, Nomor 2, Desember 2017. p.401-412.

Hersanti. 2007. Isolasi Bakteri Asal Larutan Mikroorganisme Lokal. Uji Antagonis, Uji Pertumbuhan Semai Padi. Faperta UNPAD

Hidup, K. L., \& Indonesia, K. (2016). Statistik Kementerian Lingkungan Hidup dan Kehutanan Tahun 2015 .

Indriani, Y. H. (2011). Membuat kompos secara kilat. Penebar Swadaya Grup.

Isroi. 2015. Materi Resep Pembuatan Mikro Organisme Lokal (MOL). http://isroi.com/category/pupuk/pupuk-organik-cair-pupuk/

Purwasasmita, M., \& Kunia, K. (2009, October). Mikroorganisme lokal sebagai pemicu siklus kehidupan dalam bioreaktor tanaman. In Seminar Nasional Teknik Kimia Indonesia (pp. 1920).

Ardiningtyas, T. R. (2013). Pengaruh Penggunaan Effective Microorganism 4 (EM4) dan Molase Terhadap Kualitas Kompos dalam Pengomposan Sampah Organik RSUD dr. R. Soetrasno Rembang (Doctoral dissertation, Universitas Negeri Semarang).

Yuniwati, M., \& Padulemba, A. (2012). Optimasi kondisi proses pembuatan kompos dari sampah organik dengan cara fermentasi menggunakan EM4. Jurnal Teknologi, 5(2), 172-181. 